\title{
Upaya meningkatkan hasil belajar gerak dasar manipulatif dengan menggunakan modifikasi alat bantu pembelajaran sederhana di sekolah dasar
}

\author{
Andri Arif Kustiawan *, Aba Sandi Prayoga, Arief Nur Wahyudi, A. W. B. Utomo \\ Sekolah Tinggi Keguruan dan IImu Pendidikan (STKIP) Modern Ngawi \\ J. Ahmad Yani No.99, Beran, Ngawi, Jawa Timur 63216, Indonesia. \\ ${ }^{*}$ Corresponding Author. Email: andrigww3m@gmail.com
}

\begin{abstract}
Abstrak
Tujuan penelitian ini adalah untuk meningkatkan hasil belajar kemampuan gerak dasar manipulatif menggunakan alat bantu pembelajaran sederhana pada siswa kelas II B SDN Pacitan I Kabupaten Pacitan tahun pelajaran 2018/2019. Penelitian ini merupakan penelitian tindakan kelas (PTK). Penelitian ini dilaksanakan dalam dua siklus, dengan tiap siklus terdiri atas perencanaan, pelaksanaan,observasi,dan refleksi. Subjek penelitian adalah siswa kelas II B SDN Pacitan I Kabupaten Pacitan yang berjumlah 30 siswa yang terdiri dari 20 siswa putra dan 10 siswa putri. Sumber data berasal dari guru,peserta didik,dan peneliti. Tekhnik pengumpulan data adalah dengan observasi, penilaian dan dokumentasi. Validitas data menggunakan teknik triangulasi data. Analisis data menggunakan tekhnik deskriptif yang didasarkan pada analisis kualitatif dengan prosentase. Hasil penelitian ini analisis yang diperoleh dari kondisi awal siswa yang lulus hanya 9 siswa atau 30\%, di siklus pertama siswa yang lulus menjadi 16 siswa atau 53,34\% dan di siklus kedua siswa yang lulus menjadi 26 siswa atau $86,67 \%$ sedangkan 4 siswa lainnya belum tuntas. Simpulan dari penelitian ini adalah dengan menggunakan alat bantu pembelajaran sederhana dapat meningkatkan hasil belajar kemampuan gerak dasar manipulatif pada siswa kelas II B SDN Pacitan I Kabupaten Pacitan tahun pelajaran 2018/2019.
\end{abstract}

Kata Kunci: kemampuan gerak dasar manipulatif, alat bantu pembelajaran sederhana

\section{Improve learning outcomes movement using the tools of simple manipulative learning in primary school}

\begin{abstract}
The purpose of this study was to improve the learning outcomes of manipulative basic motion abilities using simple learning aids in class II B Pacitan I SDN Pacitan District 2018/2019 academic year. This research is classroom action research (CAR). This research was conducted in two cycles, with each cycle consisting of planning, implementation, observation and reflection. The research subjects were class II B Pacitan I SDN Pacitan Regency, amounting to 30 students consisting of 20 male students and ten female students. Sources of data come from teachers, students, and researchers. Data collection techniques are by observation, assessment and documentation. Data validity uses data triangulation techniques. Data analysis using descriptive techniques based on qualitative analysis with percentages. The results of this study analysis obtained from the initial conditions of students who graduated only nine students or 30\%, in the first-cycle students who passed became 16 students or $53.34 \%$ and in the second-cycle students who graduated became 26 students or $86.67 \%$ while four other students have not yet finished. This study concludes that using simple learning aids can improve the learning outcomes of manipulative baseline skills in class II B Pacitan I SDN Pacitan District 2018/2019 academic year.
\end{abstract}

Keywords: learning outcomes movement the manipulative, simple learning tools

\section{PENDAHULUAN}

Berolahraga dapat meningkatkan kesegaran jasmani dan kondisi fisik seseorang (Muhardi \& Wijayanti, 2017), sehingga untuk melaksanakan aktivitas sehari-hari tanpa 
mengalami kelelahan yang berarti. Melalui kegiatan olahraga dapat membentuk manusia yang sehat jasmani dan memiliki watak disiplin serta sportif yang tinggi dan pada akhirnya akan membentuk manusia yang berkualitas.

Pendidikan jasmani bukan hanya merupakan bagian penting bagi kehidupan manusia saja. Pendidikan jasmani juga merupakan bagian penting dari proses pendidikan. Artinya, melalui pendidikan jasmani yang diarahkan dengan baik, anak akan mengembangkan keterampilan yang berguna bagi pengisian waktu senggang, terlibat dalam aktivitas yang kondusif untuk mengembangkan hidup sehat, berkembang secara sosial, dan menyumbang pada kesehatan fisik dan mentalnya. Pendidikan jasmani banyak permasalahan yang muncul pada saat berlangsungnya proses belajar mengajar yaitu seperti anak didik timbul sifat bermalas-malasan untuk melakukan aktivitas jasmani. Saat kegiatan belajar mengajar anak didik pura-pura sakit,jin, dan tidak mengikuti pelajaran dengan berbagai macam alasan.

Pada saat melaksanakan pembelajaran pendidikan jasmani seorang guru harus aktif menciptakan suasana pembelajaran yang sebaik mungkin agar motivasi belajar siswa dapat meningkat. Tujuan pembelajaran dapat tercapai dengan baik bila seorang guru memiliki kemampuan untuk membangkitkan motivasi siswa dalam belajar. Dalam rangka mencapai tujuan tersebut, pembelajaran yang dilakukan antara guru dan siswa hendaknya mengacu pada aktivitas dan partisipasi siswa. Guru tidak hanya melakukan kegiatan penyampaian pengetahuan,keterampilan, dan sikap kepada siswa akan tetapi guru diharapkan mampu membawa siswa untuk aktif dalam berbagai bentuk pembelajaran.

Pembelajaran pendidikan jasmani di sekolah dasar diajarkan beberapa aktivitas olahraga yang berisi berbagai macam kemampuan gerak dasar yang terangkum dalam kurikulum pendidikan jasmani. Salah satunya adalah kemampuan gerak dasar manipulatif yang meliputi gerakan melempar,menangkap dan menendang.

Kemampuan melempar, menangkap dan menendang menjadi salah satu kemampuan manipulatif yang sangat diperlukan pada masa perkembangan. Karena keterampilan ini dapat menopang terhadap kebutuhan gerak pada usia anak-anak. Adapun keterampilan lainya seperti menggiring, dan memukul diperlukan pada usia remaja dan dewasa.

Kemampuan manipulatif akan berkembang seiring bertambahnya usia dan akan lebih cepat lagi apabila diiringi serangkaian latihan belajar gerak. Siapapun anak yang normal pasti akan menguasai kemampuan melempar,menangkap dan menendang tanpa harus berlatih. Namun perlu dipertanyakan sampai manakah tingkat keterampilan ini bisa berkembang jika tidak pernah berlatih belajar gerak secara khusus.

Dalam kegiatan pembelajaran dengan materi melempar,menangkap,dan menendang dengan media bola yang telah diajarkan oleh guru di SDN Pacitan I Pacitan pada kelas II B masih terlihat biasa saja dan ketertarikan anak untuk memperbanyak gerak masih sangat kurang, hal ini dikarenakan media pembelajaran yang masih terlihat kurang bervariasi sehingga tidak dapat memotivasi anak didik untuk tertarik melakukan gerakan-gerakan. Hal ini diperparah dengan kondisi kelas dengan anak didik yang bercanda sesukanya sendiri saat materi sedang diberikan oleh guru pendidikan jasmani.

Dengan demikian maka hasil belajar kemampuan gerak dasar manipulatif melempar, menangkap dan menendang dengan media bola pun berbanding lurus dengan fakta yang ada di lapangan. Berdasarkan hasil observasi yang telah dilakukan di SDN Pacitan I Pacitan pada siswa kelas II B, hasil belajar siswa masih belum sesuai harapan dan masih banyak yang belum tuntas dari KKM atau Kriteria Ketuntasan Minimal yang telah ditetapkan. Dari 30 siswa dengan KKM 75 hanya 9 siswa atau $30 \%$ saja yang bisa dikatakan baik dan tuntas sedangkan 21 siswa atau $70 \%$ lainnya masih belum tuntas KKM.

Modifikasi Alat bantu pembelajaran sederhana merupakan sarana untuk membantu proses pembelajaran agar tujuan pembelajaran dapat dicapai oleh anak didik. Selain itu alat bantu pembelajaran sederhana juga dapat menghidupkan suasana pembelajaran agar tidak monoton. Pembelajaran yang monoton akan membuat anak didik kurang tertarik mengikuti dan melakukan materi pembelajaran yang diajarkan.

Untuk menciptakan suatu alat bantu pembelajaran yang sederhana tidak perlu mengeluarkan biaya yang banyak. Banyak sekali barang-barang yang sudah tidak terpakai 
yang bisa dimanfaatkan untuk dijadikan alat bantu pembelajaran sederhana. Dengan memperbanyak referensi dan kreatifitas maka dengan barang yang simple dan tidak terpakai atau bahkan barang yang harusnya dibuang justru dapat dijadikan alat untuk membantu proses pembelajaran di sekolah. Agar dapat mengetahui seberapa maksimal penerapan alat bantu pembelajaran sederhana ini dapat meningkatkan hasil belajar kemampuan gerak dasar manipulatif melempar, menangkap, dan menendang, maka peneliti tertarik melakukan ini.

\section{METODE}

Peneliti berkolaborasi dengan guru untuk menyelesaikan permasalahan proses pembelajaran dikelas. Peneliti mengajukan solusi untuk memecahkan proses pembelajaran dikelas berdasarkan observasi yang dilakukan peneliti. Solusi yang dimaksud adalah tindakan berupa penerapan alat bantu pembelajaran sederhana untuk meningkatkan hasil belajar kemampuan gerak dasar manipulatif pada siswa kelas II B SDN Pacitan I Kabupaten Pacitan. Penerapan alat bantu pembelajaran sederhana dilakukan secara berulang dalam setiap pembelajaranya, artinya cara menerapkan alat bantu pembelajaran sederhana dalam setiap siklusnya adalah sama baik pada siklus I maupun pada siklus II. Perbedaan terletak pada refleksi dari setiap siklus, sebab refleksi ini tergantung pada fakta dan interprestasi data yang diperoleh atau kondisi yang ada dilapangan. Refleksi dilakukan untuk memperoleh hasil yang maksimal mengenai alat bantu pembelajaran sederhana untuk meningkatkan hasil belajar kemampuan gerak dasar manipulatif pada siswa kelas II B SDN Pacitan I Kabupaten Pacitan.

Analisis data yang digunakan dalam penelitian ini analisis diskriptif dengan prosentase. Pengumpulan data menggunakan tes dan observasi dimana tes digunakan untuk mengumpulkan data dan mengukur kemampuan siswa dalam aspek kognitif atau tingkat penguasaan materi pembelajaran kemampuan gerak dasar manipulatif dalam bentuk lisan dan tertulis sedangkan observasi digunakan sebagai teknik pengumpulan data tentang hasil belajar kemampuan gerak dasar manipulatif siswa dan tentang aktifitas siswa selama mengikuti proses belajar mengajar. Uji validitasi data merupakan suatu cara untuk menentukan suatu keabsahan data yang diperoleh.dalam hal ini, untuk meningkatkan validitas data yang diperoleh, peneliti menggunakan triangulasi data dimana data yang sama akan lebih mantap kebenaranya apabila diperoleh dari beberapa sumber data yang berbeda.

\section{HASIL DAN PEMBAHASAN}

Hasil penelitian ini menunjukan bahwa dengan menggunakan alat bantu pembelajaran sederhana dapat meningkatkan hasil belajar kemampuan gerak dasar manipulatif. Hasil belajar tersebut meliputi aspek pisikomotorik, kognitif, dan afektif dari 30 siswa hanya 9 siswa yang mencapai KKM atau $30 \%$ pada kondisi awal, mengalami peningkatan menjadi $53,34 \%$ atau 16 siswa yang mencapai batas tuntas pada siklus I. Selanjutnya meningkat menjadi $86,67 \%$ atau 26 siswa yang mencapai batas tuntas pada akhir siklus II. Hasil belajar siswa pada siklus I dan II disajikan dalam Tabel 1.

Tabel 1. Deskripsi Data Hasil Belajar Gerak Dasar Manipulatif Siklus 1 pertemuan 2 Pada siswa kelas II B SDN Pacitan I Kabupaten Pacitan Tahun Pelajaran 2018/2019

\begin{tabular}{ccccc}
\hline Rentang Nilai & Kriteria & Keterangan & Jumlah Anak & Prosentase \\
\hline$>87$ & Baik Sekali & Tuntas & 0 & $0 \%$ \\
$81-86$ & Baik & Tuntas & 2 & $6,67 \%$ \\
$75-80$ & Cukup & Tuntas & 14 & $46,67 \%$ \\
$69-74$ & Kurang & Belum Tuntas & 13 & $43,33 \%$ \\
$<68$ & Kurang Sekali & Belum Tuntas & 1 & $3,33 \%$ \\
& Jumlah & & 30 & $100 \%$ \\
\hline
\end{tabular}

Berdasarkan Tabel 1 menunjukan bahwa rata-rata hasil belajar siswa yang tuntas diperoleh pada akhir tindakan siklus I sebanyak 53,34\%. Hasil ini belum menunjukan hasil yang maksimal, masih banyak nilai siswa yang dibawah KKM dan belum sesuai dengan target yang ditetapkan yaitu ketuntasan hasil belajar sebesar $80 \%$, sehingga dilanjutkan ke 
siklus II. Hal ini karena adanya beberapa kendala seperti, para siswa masih perlu adaptasi dengan pembelajaran menggunakan alat bantu pembelajaran sederhana, suasana kelas atau kelompok masih gaduh karena siswa sulit untuk di atur dan masih lemahnya pemahaman konsep gerak beberapa siswa terhadap materi kemampuan gerak dasar manipulatif.

Dari hasil pengamatan peneliti dan guru dan hasil belajar siswa yang diperoleh pada siklus kedua ini guru dapat mengerti kekurangan-kekurangan yang telah dialami selama kegiatan belajar mengajar berlangsung. Penggunaan alat bantu pembelajaran sederhana untuk meningkatkan hasil belajar kemampuan gerak dasar manipulatif diperoleh secara maksimal.

Peneliti juga telah berhasil membangkitkan semangat siswa untuk mengikuti kegiatan belajar mengajar dengan tertib. Siswa juga tidak cepat bosan dan semakin termotivasi dengan materi pembelajaran yang diberikan, siswa telah mampu melakukan gerakan dengan baik, walaupun masih ada beberapa siswa yang kurang baik.

Tabel 2. Deskripsi Hasil Belajar Gerak Dasar Manipulatif Siklus 2 pertemuan 2 Pada siswa kelas II B SDN Pacitan I Kabupaten Pacitan Tahun Pelajaran 2018/2019

\begin{tabular}{ccccc}
\hline Rentang Nilai & Kriteria & Keterangan & Jumlah Anak & Prosentase \\
\hline$>87$ & Baik Sekali & Tuntas & 3 & $10 \%$ \\
$81-86$ & Baik & Tuntas & 7 & $23,33 \%$ \\
$75-80$ & Cukup & Tuntas & 16 & $53,34 \%$ \\
$69-74$ & Kurang & Belum Tuntas & 4 & $13,33 \%$ \\
$<68$ & Kurang Sekali & Belum Tuntas & 0 & $0 \%$ \\
& Jumlah & & 30 & $100 \%$ \\
\hline
\end{tabular}

Dari diskripsi data pada tabel 2 terlihat bahwa hasil belajar siswa sudah cukup baik dengan ketuntasan hasil belajar mencapai $86,67 \%$, ini berarti proses belajar mengajar telah dikatakan berhasil karena telah melebihi indikator ketuntasan hasil belajar dari $80 \%$, meskipun masih terdapat 4 orang (13,33\%) siswa yang belum tuntas, hal ini disebabkan karena ada beberapa orang diantara siswa masih merasa kurang percaya diri dalam mengikuti pembelajaran sehingga tidak maksimal dalam memperoleh hasil belajarnya dan artinya keaktifan dan kemampuan siswa meningkat sesuai yang diharapkan dan pembelajaran dinyatakan berhasil meningkatkan hasil belajar siswa. Dengan alat bantu pembelajaran sederhana yang di gunakan oleh peneliti dan guru mampu mengubah kondisi kelas menjadi lebih baik, sehingga proses belajar mengajar dan pemberian materi bisa berlangsung lebih maksimal, melihat hasil yang diperoleh pada tindakan II maka Penelitian Tindakan Kelas telah memenuhi target dari rencana terget yang telah ditentukan. Dan dirasa sudah optimal sesuai dengan yang diharapkan.

\section{SIMPULAN}

Penelitian tindakan kelas yang dilakukan pada siswa kelas II B SDN Pacitan I Kabupaten Pacitan tahun pelajaran 2018/2019 ini dilakukan dalam dua siklus dan berjalan dengan lancar. Dalam setiap siklus terdiri dari 4 tahapan, yaitu: (1) perencanaan tindakan, (2) pelaksanaan tindakan, (3) observasi tindakan, (4) refleksi. Pada kondisi awal siswa yang tuntas sebanyak 9 siswa atau $30 \%$. Pada siklus 1 siswa yang tuntas sebanyak 16 siswa atau 53,34 \% dan pada siklus 2 siswa yang tuntas menjadi 26 siswa atau 86,67\%. Berdasarkan analisis data yang telah dilakukan dan pembahasan yang telah dipaparkan dalam BAB IV diperoleh simpulan sebagai berikut:

Bahwa dengan menggunakan alat bantu pembelajaran sederhana dapat meningkatkan hasil belajar kemampuan gerak dasar manipulatif pada siswa kelas II B SDN Pacitan I Kabupaten Pacitan tahun pelajaran 2018/2019. Hal ini dibuktikan dengan analisis data yang telah dilakukan bahwa terdapat peningkatan yang signifikan pada tiap siklus dan di setiap pertemuan di tiap siklus. 


\section{DAFTAR PUSTAKA}

Arikunto, S. (2006). Prosedur penelitian, suatu pendekatan praktis. Jakarta: Rineka Cipta.

Atmojo, M.B. (2008). Tes dan pengukuran pendidikan jasmani olahraga. Surakarta: UNS Press.

Coerver, W. (1985). Sepak bola program pembinaan pemain ideal. Jakarta: PT Gramedia

FIFA. (2008). Physical preparation/ development and training. Zurich

Hidayatullah, M.F. (2008). Mendidik anak dengan bermain. buku pegangan guru pendidikan jasmani di sekolah dasar. Universitas Sebelas Maret Surakarta

Kern, R. (2000). Literacy \& language teaching. Oxford : Oxford University Press.

Muhardi, M., \& Wijayanti, N. P. N. (2017). Tingkat kesegaran jasmani siswa SMPN 1 Bangko Kabupaten Rokan Hilir. Jurnal Online Mahasiswa (JOM) Bidang Keguruan dan IImu Pendidikan, 3(2), 1-10.

Sugiyono, (2015). Metode penelitian pendidikan. Bandung: Alfabeta.

Wahab, J.A. (2013). Belajar dan pembelajaran. Bandung: Pustaka Reka Cipta. 